\title{
Sarcoidosis Presenting with Inguinal Lympadenopathy and Treated with a Combination of Corticosteroids and Aazothioprine
}

\author{
İnguinal Lenfadenopati ile Seyreden ve Kortikosteroid ve Azotoprin Kombinasyonu ile \\ Tedavi Edilen Sarkoidoz
}

\author{
Metin IŞIK \\ Department of Internal Medicine, Medical Faculty of Hacettepe University, Division of Rheumatology, Ankara, Turkey
}

Sarcoidosis is a systemic inflammatory disorder characterized by noncaseating granulomas which mostly affect the lungs, intrathoracic lymph nodes, eyes, and skin. The defining histopathology is the presence of compact, epithelioid granulomas associated with mononuclear cell infiltration. ${ }^{[1]}$ Sarcoidosis may present as an asymptomatic disease, or it may cause respiratory insufficiency, blindness, severe neurological disease, or sometimes cardiac death. ${ }^{[2,3]}$ The involvement of inguinal lymph nodes in sarcoidosis is very rare and has been reported only in a few cases before.

A 50-year-old female diabetic patient applied to our outpatient unit complaining of inguinal pain and a mass which had lasted for three months. She did not report fever, weight loss, or a history of tuberculosis but complained of sweating and pain. The ultrasonographic evaluation of the inguinal region revealed bilaterally enlarged lymph nodes of nearly 25 millimeters in diameter. A pathological evaluation of the biopsy taken from the inguinal lymph nodes showed noncaseating necrotizing granulomas which were positive for CD3 and CD20, but negative for $\mathrm{CD} 30$, periodic acid-Schiff (PAS), and angiotensin II receptor blockers (ARBs). For further evaluation, a thoracic computed thomography (CT) scan was performed, and similar enlarged lymph nodes were present in both hilar sides and also in the mediastinum. After the exclusion of other diseases which cause granuloma formation, the patient was diagnosed with sarcoidosis, and azothioprine $100 \mathrm{mg} /$ day and prednisolone $16 \mathrm{mg}$ every 48 hours was prescribed. After four months of treatment, the inguinal lymph nodes all disappeared, and she is currently doing well.

In 1959, Monnet and Thevenon ${ }^{[4]}$ reported a patient with sarcoidosis who was diagnosed by an inguinal lymph node biopsy, although it was not the presenting symptom. Similarly Mandi et al. ${ }^{[5,6]}$ reported that an inguinal lymph node biopsy may help in the diagnosis of sarcoidosis, even if none of the patients have inguinal lymphadenopathy.

Nevertheless, to our knowledge, our case is the probably the first with sarcoidosis presented with inguinal lymphadenopathy. The other important point in this case is the preferred treatment option. Most authors do not offer any treatment to their patients if there are no prominent symptoms because sarcoidosis may regress spontaneously. ${ }^{[1]}$ For the remaining patients, corticosteroids alone are the first choice (10-20 mg a day), but if corticosteroidsparing agents are necessary, then methotrexate or azothioprine are the best choices. ${ }^{[7]}$ In our case, the patient was diabetic. Since higher steroid doses can impair glucose levels, we preferred to begin the

Received: November 27, 2011 Accepted: March 12, 2012

Correspondence: Metin Işık, M.D. Hacettepe Üniversitesi Tıp Fakültesi İç Hastalıkları Anabilim Dalı, Romatoloji Bilim Dalı, 06100 Sıhhiye, Ankara, Turkey. Tel: +90 312 - 3051450 e-mail: metin1721978@yahoo.com

(C)2012 Turkish League Against Rheumatism. All rights reserved. 
treatment with lower doses of corticosteroids the day after protocol. In additon, we added a steroid-sparing agent to obtain a better result.

In conclusion, sarcoidosis may present with inguinal lymphadenopathy, and the treatment should be personalized.

\section{Declaration of conflicting interests}

The author declared no conflicts of interest with respect to the authorship and/or publication of this article.

\section{Funding}

The author received no financial support for the research and/or authorship of this article.

\section{REFERENCES}

1. Chen ES, Moller DR; Medscape. Sarcoidosis-scientific progress and clinical challenges. Nat Rev Rheumatol 2011;7:457-67. doi: 10.1038/nrrheum.2011.93.
2. Iannuzzi MC, Rybicki BA, Teirstein AS. Sarcoidosis. N Engl J Med 2007;357:2153-65.

3. Baughman RP, Teirstein AS, Judson MA, Rossman MD, Yeager H Jr, Bresnitz EA, et al. Clinical characteristics of patients in a case control study of sarcoidosis. Am J Respir Crit Care Med 2001;164:1885-9.

4. Monnet P, Thevenon J. Sarcoidosis with clinically isolated mediastinal adenopathy; diagnosis confirmed by biopsy of inguinal \& right pre-scalenic lymph nodes. Lyon Med 1959;91:191-5. [Abstract]

5. Mándi L, Kelemen JT, Bacsa S. Biopsy examinations in sarcoidosis: inguinal lymph node biopsy. Panminerva Med 1967;9:39-44.

6. Mándi L, Kelemen J, Bacsa S. Bioptic studies on sarcoidosis, inguinal lymph node biopsy. Orv Hetil 1966;107:1650-3. [Abstract]

7. Barnett CF, Bonura EJ, Nathan SD, Ahmad S, Shlobin OA, Osei K, et al. Treatment of sarcoidosis-associated pulmonary hypertension. A two-center experience. Ches 2009;135:1455-61. 